\title{
Profile of Bi-voltine Silkworm Rearing Farmers of Chitradurga District, India
}

\author{
Imrankhan Jiragal", R. Golya Naik, M.V. Srinivasa Reddy, \\ Mahinsharif and T.L. Mohankumar
}

Department of Agricultural Extension, UAS, GKVK, Bengaluru and COS, Chintamani, Karnataka, India

*Corresponding author

\section{A B S T R A C T}

\begin{tabular}{|l|}
\hline K e y w o r d s \\
Sericulture, \\
Education, Annual \\
income and \\
Extension \\
participation
\end{tabular}

Keywords

Sericulture,

Education, Annual

income and

Extension

participation

Accepted:

Available Online:

10 September 2019

\begin{abstract}
Sericulture is an agro based industry providing lively hood to about seven million of rural people in India. Karnataka has more than 45.35 per cent of the total area under mulberry cultivation contributing over 44.25 per cent of silk produced in the country. The study was conducted in the year 2017-2018 in Molakalmuru, Challakere and Hiriyurtaluks of Chitradurga district in Karnataka. From this district among the 120 respondents were selected.Results revealed that over one-third $(36.67 \%)$ of Bi-voltine silkworm rearing respondents belong to middle age category, 30 per cent of Bi-voltine silkworm rearing farmers had PUC level of education. In respect to annual income,39.17 per cent of the Bivoltine silkworm rearing farmers belonged to upto 1 lakh income category. Majority of respondents $(60.83 \%)$ farmers belong to high level of risk orientation, majority $(59.00 \%)$ of the farmers belong to high mass media participation .More than half $(51.67 \%)$ of the Bi-voltine silkworm rearing farmers belonged to high extension agency contact and majority $(70.00 \%)$ of the Bi-voltine silkworm rearing farmers belong to high extension participation category.
\end{abstract}

\section{Introduction}

Sericulture is an agro based industry providing lively hood to about seven million of rural people in India. As sericulture activities comprises of both on farm and nonfarm activities it provides immense employment potential for both men and women alike. Of the four major types of silks namely, Tasar, Eri and Muga produced in India, Mulberry silk occupies the major portion and mainly produced in the three southern states namely Karnataka, Andhra Pradesh and Tamil Nadu and West Bengal in eastern part of the country. Because of new technology development and technology dissemination, number of modern sericulture activities is being implemented at the field level contributing to the higher silk output and in turn betterment of farmer's income.

Rearing of silkworm is an art and science, popularly known as sericulture. India is the second largest producer of silk after China and biggest consumer of Raw silk and silk fabric. In India Karnataka stands first in area 
20,89,447 ha and 2,85,233 M.T production. Sericulture in Karnataka is being practiced mainly in southern part of the state for many decades. Now, it is spreading across the state especially the rearing of $\mathrm{Bi}$-voltine silk worms in non-traditional sericulture areas of the Karnataka state. Bi-voltine silk production has been one of the priority sectors of Indian silk Industry to make sericulture a sustainable commercial activity by meeting the international silk standards, enhancing productivity and processing of cocoons rearing of $\mathrm{Bi}$-voltine silk worms plays a significant role but its production is yet to meet the targets.

Out of 16500 M.T of the country's total raw silk production, 14620 M.T was of the mulberry type, While, eri, muga and tasar silks accounted for 8.7, 0.65 and 1.9 per cent of total production respectively. The country has a monopoly in muga and is one of the leading producer of tasar silk in the world. Karnataka occupies the pride place in the sericulture map of India. Karnataka is known as the fables land of 'Sandal and silk', has more than 45.35 per cent of the total area under mulberry cultivation contributing over 44.25 per cent of silk produced in the country. Mulberry occupies an area of 91,491 hectares with a production of 9,8,222 M.T of raw silk. About 87 per cent in the states mulberry area and 93 per cent of its cocoon production is concentrated in traditional areas of Karnataka Mysore, Kolar, Chitradurga, Bangalore, Tumkur and Mandya districts.

However, there is a lacuna in the technology dissemination and adoption of improved practices by the farmers. Hence, the present study is conducted to know the gap in the adoption of improved sericulture practices and the associated factors contributing for the success and failure of sericulture in Chitradurga district of Karnataka. Studies on the personal socio-economic and communication characteristics in adoption pattern and its level of profits obtained by adopting the hybrid variety of Bi-voltine silkworm rearing in Karnataka are scanty Hence, owing to the increasing importance of hybrid Bi-voltine silkworm rearing and its importance in rural areas, the present study was undertaken with the following specific objectives: To study the profile of socioeconomic, psychological and communication characteristics of Bi-voltine silkworm rearing farmers of Chitradurga District.

\section{Materials and Methods}

The study was conducted during March-April 2018 and an Ex-post facto research design was followed to assess the 120 Bi-voltine Silkworm rearing farmers through personal interview method. Chitradurga district was selected purposively owing to more area and production under $\mathrm{Bi}$-voltine silkworm rearing and assured irrigation facility. Chitradurga district has six taluks, out of which Molakalmuru, Challakere and Hiriyurtaluks were selected purposively for the study considering the higher area under Bi-voltine silkworm rearing practices.

\section{Personal, socio-economic and psychological characteristics of Bi-voltine silkworm rearing farmers in Chitradurga district}

\section{Age}

The results presented in the table 1 revealed that most of the respondents $(36.67 \%)$ belonged to middle age category followed by 34.16 and 29.17 per cent belonging to old and young age categories, respectively. A critical observation of the above findings indicated that a considerable percentage of the $\mathrm{Bi}$ voltine silkworm rearing farmers were of middle age. The possible reason for the above trend might be, the middle aged hybrid $\mathrm{Bi}$ voltine silkworm rearing farmers were 
comparatively have free hand in financial affair and they can take up independent decision to implement their ideas. Further, the middle-aged Bi-voltine silkworm rearing farmers were enthusiastic, possess more physical vigor and have more work efficiency than older and younger $\mathrm{Bi}$-voltine silkworm rearing farmers. The results of the study was in conformity with the findings of Nirmala (2012)

\section{Education}

The result presented in the table 1 reveals that 30 per cent of $\mathrm{Bi}$-voltine silkworm rearing farmers had PUC level of education, 24.17 per cent of the farmers had high school level of education, 15.83 per cent of the farmers had middle school level of education, 12.50 per cent of the farmers had primary school level of education, 9.17 per cent of the Bi-voltine silkworm rearing farmers had illiterate and 8.33 per cent of the Bi-voltine silkworm rearing farmers had graduation level of education. The probable reason for majority of Bi-voltine silkworm rearing farmers to be educated up to PUC and graduation might be due to their high annual family income, proper facilities for college education in nearby village. The reason behind illiterates could be their lack of interest, lack of encouragement from family members and their poor economic status. This is in line with the findings of Nirmala (2012), Kiran and Shenoy (2010).

\section{Annual income}

It could be observed from the Table 1 that 39.17 per cent of the Bi-voltine silkworm rearing farmers belonged to upto 1 lakh income category whereas, 37.50 per cent of the farmers belonged to income category between 1 lakh to 2 lakh and 23.33 per cent of the farmers belonged to more than 3 lakh income category. The probable reason, which could be attributed for varied income categories of $\mathrm{Bi}$-voltine silkworm rearing farmers, might be due to the size of the land holding and practicing of subsidiary occupations by the respondents. The results are in line with the findings of Preethi (2015).

\section{Size of family}

It is clear from Table 1 that $46.66 \%$ per cent of the Bi-voltine silkworm rearing farmers were having medium sized family followed by big $(27.50 \%)$ and small $(25.84 \%)$ families, respectively. The reason for this might be that majority of the respondents had nuclear families. Above findings are in line with the findings of Beerannavar (1995)

\section{Attitude towards sericulture}

It could be observed from Table 1 that 50 per cent of the Bi-voltine silkworm rearing farmers belonged to high attitude towards sericulture whereas, 25.84 per cent and 24.16 per cent of the Bi-voltine silkworm rearing farmers belonged to low and medium attitude towards sericulture categories, respectively. Above findings are in line with the findings of Sunderrao (1988)

\section{Innovativeness}

This refers to the degree to which an individual is relatively earlier in adopting the new ideas when compared to other members in society. The result from table 1 shows that majority of respondents $(47.50 \%)$ belong to medium level of innovativeness followed by high level of innovativeness 45.00 per cent and 7.50 per cent belongs to low level of innovativeness. Innovativeness is a cognitive aspect of change, which affects the readiness of an individual to accept new technology. Innovativeness plays a greater role in the individuals' personality. The findings of the study was in consonance with the findings of Balasubramanians (1997), 


\section{Achievement motivation}

It is observed from table 1 that majority of respondents $(47.50 \%)$ belong to high level of achievement motivation followed by 39.17 per cent had low level achievement motivation followed by 13.33 per cent belongs to medium level of achievement motivation. The probable reason could be achievement motivation was individual's effort to achieve some establishes goals. The results are in line with the findings of Birajdar (2002).

\section{Scientific orientation}

It is observed from the Table 2 that 46.67 per cent of the Bi-voltine silkworm rearing farmers belongs to medium level of scientific orientation, followed by high level of risk orientation $(35.83 \%)$ and low level of risk orientation $(17.50 \%)$. The results are in line with the findings of Sarvankumar (1996).

\section{Economic motivation}

It is clear from the Table 2 that the high economic motivation was noticed among 48.34 per cent and medium level of economic motivation was exhibited by 33.33 per cent and 18.33 per cent were found to have low economic motivation. The reason for medium economic motivation of the respondents might be due to low economic position of the respondents and most of the decisions were made by the male member of the family and their responsibilities of women were restricted to care and management of dairy animals. The findings of the study was in consonance with the findings of Sreenivasredddy (1995).

\section{Risk orientation}

It is observed from the Table 2 that 60.83 per cent of the Bi-voltine silkworm rearing farmers belongs to high level of risk orientation, followed by low level of risk orientation $(22.50 \%)$ and medium level of risk orientation $(16.67 \%)$. The reason for this might be illiteracy and the respondents are not in a position to withstand economic losses. The above finding was inconsonant with the finding of Natikar (2001).

\section{Social participation}

It is evident from the Table 2 that 49.17 per cent of Bi-voltine silkworm rearing farmers belonged to high level of social participation category followed by medium (45.00\%) level of social participation, whereas only 5.83 per cent of farmers belong to low level of social participation categories. Social participation encourages hybrid Bi-voltine silkworm rearing farmers to establish contact with the support system, which can promote farmers to take up mulberry cultivation and silkworm rearing. For medium and high social participation, the reason could be the Bi-voltine silkworm rearing farmers with formal education and good economic conditions were keen to participate in social organizations for getting some social status. While low social participation was due to lack of interest and time, non-attractiveness of the activities undertaken by the organizations, lack of perceived benefits and local political hinder them to participate actively in social activities. Similar trend was reported by Rizwana (2006).

\section{Mass media participation}

It could be observed from the Table 2 that 49.17 per cent of the Bi-voltine silkworm rearing farmers belonged to high mass media participation category. Whereas, 30.00 per cent and 20.83 per cent of the Bi-voltine silkworm rearing farmers belonged to medium and low mass media participation categories, respectively. The above trend might be due to the fact that mass media were the proven channels for quick dissemination of topical 
information to a widely dispersed and large number of people in a shorter period. Mass media contact enhances the ability of Bivoltine silkworm rearing farmers to get more information about a technology or innovation and in turn widens the mental horizon of the Bi-voltine silkworm rearing farmers to accept and adopt the practices. Mass media provides information on experiences of successful Bivoltine silkworm rearing farmers through various channels like television, radio, newspaper etc., which reinforces confidence in other Bi-voltine silkworm rearing farmers to take up similar activities or try out new innovations. The results were in conformity with the findings of Painkra (2010).

Table.1 Personal characteristics of Bi-voltine silkworm rearing farmers $(\mathrm{n}=120)$

\begin{tabular}{|c|c|c|c|c|}
\hline \multirow{2}{*}{$\begin{array}{l}\text { Sl. } \\
\text { No. }\end{array}$} & \multirow[t]{2}{*}{ Characteristics } & \multirow[t]{2}{*}{ Category } & \multicolumn{2}{|c|}{ Respondents } \\
\hline & & & No. & $\%$ \\
\hline \multirow[t]{3}{*}{1} & \multirow{3}{*}{ Age } & Young (<35 years) & 41 & 34.16 \\
\hline & & Middle (35-50 years) & 44 & 36.67 \\
\hline & & Old ( $>50$ years $)$ & 35 & 29.17 \\
\hline \multirow[t]{6}{*}{2} & \multirow[t]{6}{*}{ Education } & Illiterate & 11 & 9.17 \\
\hline & & Primary & 15 & 12.50 \\
\hline & & Middle school & 19 & 15.83 \\
\hline & & High school & 29 & 24.17 \\
\hline & & PUC/ITI/Diploma & 36 & 30.00 \\
\hline & & Graduation & 10 & 8.33 \\
\hline \multirow[t]{3}{*}{3} & \multirow[t]{3}{*}{ Annual income } & $<1$ lakh & 47 & 39.17 \\
\hline & & Between 1,00,000-2,00,000 Lakhs & 45 & 37.50 \\
\hline & & $>3$ Lakhs & 28 & 23.33 \\
\hline \multirow[t]{3}{*}{4} & \multirow[t]{3}{*}{ Size of family } & Small $(<4)$ & 31 & 25.84 \\
\hline & & Medium (4-8) & 56 & 46.66 \\
\hline & & $\operatorname{Big}(>8)$ & 33 & 27.50 \\
\hline \multirow[t]{3}{*}{5} & \multirow{3}{*}{$\begin{array}{l}\text { Attitude towards sericulture } \\
(\text { Mean=3.52 SD=1.38) }\end{array}$} & Low $(<2.83)$ & 31 & 25.84 \\
\hline & & Medium (2.83-4.21) & 29 & 24.16 \\
\hline & & $\operatorname{High}(>4.21)$ & 60 & 50.00 \\
\hline \multirow[t]{3}{*}{6} & \multirow{3}{*}{$\begin{array}{l}\text { Innovativeness } \\
(\text { Mean=16.85 SD=2.30) }\end{array}$} & Low $(<15.70)$ & 9 & 7.50 \\
\hline & & Medium (15.70-18) & 57 & 47.50 \\
\hline & & $\operatorname{High}(>18)$ & 54 & 45.00 \\
\hline \multirow[t]{3}{*}{7} & \multirow{3}{*}{$\begin{array}{l}\text { Achievement motivation } \\
(\text { Mean=33.37 SD=1.65) }\end{array}$} & Low $(<32.55)$ & 47 & 39.17 \\
\hline & & Medium (32.55-34.19) & 16 & 13.33 \\
\hline & & High $(>34.19)$ & 57 & 47.50 \\
\hline
\end{tabular}


Table. 2 Socio- economic and communication characteristics of Bi-voltine silkworm rearing farmers

\begin{tabular}{|c|c|c|c|c|}
\hline \multirow{2}{*}{$\begin{array}{l}\text { Sl. } \\
\text { No. }\end{array}$} & \multirow[t]{2}{*}{ Characteristics } & \multirow[t]{2}{*}{ Category } & \multicolumn{2}{|c|}{ Respondents } \\
\hline & & & No. & $\%$ \\
\hline \multirow[t]{3}{*}{8} & \multirow{3}{*}{$\begin{array}{l}\text { Scientific orientation } \\
(\text { Mean }=40.30)(S D=1.65)\end{array}$} & Low $(<39.48)$ & 21 & 17.50 \\
\hline & & Medium (39.48-41.13) & 56 & 46.67 \\
\hline & & High $(>41.13)$ & 43 & 35.83 \\
\hline \multirow[t]{3}{*}{9} & \multirow{3}{*}{$\begin{array}{l}\text { Economic motivation } \\
(\text { Mean=23.81 })(\mathrm{SD}=2.00)\end{array}$} & Low $(<22.81)$ & 22 & 18.33 \\
\hline & & Medium (22,81-24.81) & 40 & 33.33 \\
\hline & & $\operatorname{High}(>24.81)$ & 58 & 48.34 \\
\hline \multirow[t]{3}{*}{10} & \multirow{3}{*}{$\begin{array}{l}\text { Risk orientation } \\
(\text { Mean=39.839) }(\mathrm{SD}=1.78)\end{array}$} & Low $(<38.94)$ & 27 & 22.50 \\
\hline & & Medium (38.94-40.72) & 20 & 16.67 \\
\hline & & High $(>40.72)$ & 73 & 60.83 \\
\hline \multirow[t]{3}{*}{11} & \multirow{3}{*}{$\begin{array}{l}\text { Social participation } \\
(\text { Mean }=10.68)(\mathrm{SD}=1.40)\end{array}$} & Low $(<9.98)$ & 7 & 5.83 \\
\hline & & Medium (9.98-11.38) & 54 & 45.00 \\
\hline & & High $(>11.38)$ & 59 & 49.17 \\
\hline \multirow[t]{3}{*}{12} & \multirow{3}{*}{$\begin{array}{l}\text { Mass media participation } \\
(\text { Mean }=6.39)(\mathrm{SD}=3.21)\end{array}$} & Low $(<4.79)$ & 25 & 20.83 \\
\hline & & Medium (4.79-7.99) & 36 & 30.00 \\
\hline & & High $(>7.99)$ & 59 & 49.17 \\
\hline \multirow[t]{3}{*}{13} & \multirow{3}{*}{$\begin{array}{l}\text { Extension agency contact } \\
(\text { Mean=10.65) }(\mathrm{SD}=1.36)\end{array}$} & Low $(<9.97)$ & 25 & 20.83 \\
\hline & & Medium (9.97-11.33) & 33 & 27.50 \\
\hline & & High $(>11.33)$ & 62 & 51.67 \\
\hline \multirow[t]{3}{*}{14} & \multirow{3}{*}{$\begin{array}{l}\text { Extension participation } \\
(\mathrm{Mean}=14.26)(\mathrm{SD}=2.02)\end{array}$} & Low $(<13.25)$ & 22 & 18.33 \\
\hline & & Medium (13.35-15.27) & 14 & 11.67 \\
\hline & & High $(>15.27)$ & 84 & 70.00 \\
\hline
\end{tabular}

\section{Extension agency contact}

It is evident from the Table 2 that majority $(51.67 \%)$ of the Bi-voltine silkworm rearing farmers belonged to high extension agency contact category. Whereas, 27.50 and 20.83 per cent of Bi-voltine silkworm rearing farmers belonged to medium and low extension agency contact categories, respectively. This trend might be sometimes due to the availability of labor alone in $\mathrm{Bi}$ voltine silkworm rearing farmers during extension worker visit without field owners. It might also due to unorganized extension work and low awareness of farmers about the importance of extension work. The results were in conformity with the findings of Gangadhara (2006). 


\section{Extension participation}

It is quite clear from the Table 2 that 70.00 per cent of the Bi-voltine silkworm rearing farmers belonged to high extension participation category followed by low (18.33 $\%)$ and medium (11.67\%) extension participation categories, respectively. The pertinent reason for majority of Bi-voltine silkworm rearing farmers belonged to medium category because of their interest in extension activities to gather recent information and their educational status also influences their participation in extension activities. The results were in conformity with the findings of Krishnamurthy (1999).

In conclusion, the study was conducted during March-April 2018 in Chitradurga district. Molakalmuru, Challakere, and Hiriyurtaluks were selected considering the highest area under hybrid Bi-voltine silkworm rearing practices. Results revealed that over one-third (36.67\%) of Bi-voltine silkworm rearing respondents belong to middle age category, 30 per cent of farmers had PUC level of education. In respect to annual income,39.17 per cent of the farmers belonged to upto 1 lakh income category, whereas, Two fourth of farmers belonged to high attitude towards $\mathrm{Bi}$ voltine silkworm rearing.

A greater proportion $(47.50 \%)$ of the respondents belong to medium level of innovativeness, a large number $(47.50 \%)$ of the respondents belong to high level of achievement motivation .More number (46.67\%) of the Bi-voltine silkworm rearing farmers belongs to medium level of scientific orientation, majority of respondents $(60.83 \%)$ farmers belong to high level of risk orientation, $(59.00 \%)$ of the farmers belong to high mass media participation .More than half $(51.67 \%)$ of the Bi-voltine silkworm rearing farmers belonged to high extension agency contact and majority $(70.00 \%)$ of the
Bi-voltine silkworm rearing farmers belong to high extension participation category.

\section{References}

Beerannavar, B., 1995, A study on knowledge and adoption of improved dairy practices by farmers trained by KVK, Hanumanahatti, Dharwad district. M. Sc. (Agri.) Thesis, (Unpub.), Univ. Agric. Sci., Bangalore.

Birajdar, V. M., 2002, Study on knowledge level of farmers and extension personnel about the ill-effects of agricultural chemicals. M. Sc. (Agri.) Thesis, (Unpub.), Univ. Agric. Sci., Dharwad.

Gangadhara, M. S., 2006, A study on knowledge, perception and decision making among demonstrator and nondemonstrator farmers of aerobic rice cultivation in eastern dry zone of Karnataka.M.Sc. (Agri.) thesis, (Unpub.), Univ. Agric. Sci., Bangalore.

Kiran, S. and Shenoy, S. S. 2010.Constraints in adoption of system of rice intensification in Warangal district of Andhra Pradesh.Journal of Research ANGRAU, 38 (1 \& 2): 77-85.

Krishnamurthy, B., 1999, An analysis of impact of the farmer field school on integrated pest management in rice. Ph.D. (Agri.) Thesis, (Unpub.), Univ. Agric. Sci., Bangalore.

Natikar, K. V., 2001, Attitude and use of farm journal by the subscribers farmers and their profile. A critical analysis.Ph.D. Thesis, (Unpub.), Univ. Agric. Sci., Dharwad.

Nirmala, K. 2012. A study on diffusion status and adoption of System of Rice Intensification (SRI) in Mahaboobnagar district of Andhra Pradesh.M. Sc. (Ag.) Thesis. (Unpub.), Acharya N.G. Ranga Agricultural University.

Painkra, S.K., Dev, C. M. and Mandal, B.K. 
2010.Information sources of tribal rice growers of Bastar district of Chhattisgarh. Journal of Communication Studies.28(9):135-139. Preethi, 2015, A study on Perception, Aspiration and Participation of farm youth in agriculture. Ph.D. (Agri.), Thesis, (Unpub.), Univ. Agric. Sci., Bangalore.

Rizwana, 2006, Gender issues in rice production technology in Raipur district of Chhattisgarh state.Ph.D. Thesis (Unpub.), Univ. Agric. Sci., Bangalore. Sreenivasreddy, M. V., 1995, A study on knowledge and adoption of recommended mango cultivation practices among farmers of Kolar district. M. Sc. (Agri.) Thesis, (Unpub.), Univ. Agric. Sci., Bangalore.

Sunderrao, D., 1988, Impact of improved dryland agricultural technology in chevella and Pothulaboguda model watershed development project in Jogipettaluk of Medak district in Andhra Pradesh. M. Sc. (Agri.) Thesis, (Unpub.), Andhra Pradesh Agricultural University, Hyderabad.

\section{How to cite this article:}

Imrankhan Jiragal, R. Golya Naik, M.V. Srinivasa Reddy, Mahinsharif and Mohankumar, T.L. 2019. Profile of Bi-voltine Silkworm Rearing Farmers of Chitradurga District, India. Int.J.Curr.Microbiol.App.Sci. 8(09): 964-971. doi: https://doi.org/10.20546/ijcmas.2019.809.114 